\title{
KESANTUNAN TINDAK TUTUR INTROGATIF DOSEN DALAM PEMBELAJARAN DI KELAS: STUDI KASUS DI PRODI PENDIDIKAN BAHASA DAN SASTRA INDONESIA FKIP UM MATARAM
}

\author{
Habiburrahman 1, Arpan Islami Bilal * \\ 1* Program Studi Pendidikan Bahasa dan Sastra Indonesia, FKIP-Universitas Muhammadiyah Mataram
}

\section{INFO ARTIKEL}

\section{Riwayat Artikel:}

Diterima: 12-05-2018

Disetujui: 20-07-2018

\section{Kata Kunci:}

lecturer introgative speech act

politeness value

\section{A. LATAR BELAKANG}

Dalam komunikasi, kesantunan merupakan aspek penting dalam kehidupan untuk menciptakan komunikasi yang baik di antara penutur dan mitratutur (Pranowo, 2012:6). Dalam konteks tersebut, kesantunan menjadi penting untuk diperhatikan guna mengatasi kesalahpahaman yang dapat menimbulkan retaknya hubungan yang tidak harmonis dalam masyarakat yang didakwahi.

Saat ini, dosen memiliki peranan yang penting untuk membentuk karakter dan budaya calon guru
ABSTRAK

Abstrak: Dalam komunikasi, kesantunan merupakan aspek penting dalam kehidupan untuk menciptakan komunikasi yang baik di antara penutur dan mitra tutur. Kaitan hubungan bahasa dengan realitas sosial tercermin pula pada proses pembelajaran di kelas dalam menciptakan suasana kampus yang harmonis. Tujuan penelitian ini adalah 1) untuk mendeskripsikan bentuk tindak tutur introgatif dosen dalam pembelajaran di kelas, dan 2) untuk mendeskripsikan kesantunan tindak tutur introgatif dosen dalam pembelajaran di kelas. Penelitian ini tergolong penelitian deskriptif kualitatif. Pengumpulan data dalam penelitian ini berkaitan dengan hal-hal sebagai berikut: (1) persiapan pengumpulan data, (2) teknik observasi, dan (3) teknik wawancara. Hasil penelitian menunjukkan beberapa bentuk klasifikasi tindak tutur introgatif (pertanyaan). Tindak tutur introgatif yang diungkapkan oleh dosen dibagi menjadi dua, yaitu: 1) bentuk tindak tutur introgatif berdasarkan maksud pengajuannya dapat diklasifikasikan menjadi empat jenis, yaitu: pertanyaan permintaan, pertanyaan retoris, pertanyaan mengarahkan atau menuntun, dan pertanyaan menggali; dan 2) bentuk tindak tutur introgatif berdasarkan tingkat kesulitan jawaban yang diharapkan dapat diklasifikasikan menjadi enam, yaitu: pertanyaan pengetahuan, pertanyaan pemahaman, pertanyaan aplikatif, pertanyaan analisis, pertanyaan sintesis, dan pertanyaan evaluasi. Sedangkan bentuk kesantunan tindak tutur introgatif dapat dibedakan menjadi strategi kesantunan negatif dan strategi kesantunan positif. Strategi kesantunan negatif ada tiga, yaitu 1) kesantunan dengan menggunakan pagar; 2) kesantunan dengan meminimalkan paksaan; dan 3) kesantunan dengan memberikan penghormatan. Sementara strategi kesantunan positif ada dua, yaitu 1) kesantunan dengan menghindari ketidaksetujuan dengan pura-pura setuju, persetujuan yang semu (psedo agreement), menipu untuk kebaikan (mhite lies), atau pemagaran opini (hedging opinicon); dan 2) kesantunan dengan menunjukkan keoptimisan. melalui pembelajaran di kelas saat mengisi perkuliahan. Pendidikan yang diberikan dosen tentang pengajaran kesantunan ini memiliki potensi besar dalam membangun kesadaran masyarakat yang berbudaya agar menghindari penyimpangan, dan mengatasi kesalahpahaman yang terjadi. Tatanan kehidupan yang dihadapkan pada kasus tawuran antarmahasiswa yang marak terjadi, pada dasarnya diawali dari bahasa komunkasi sehari-hari.

Beranjak dari uraian tersebut, amanah yang diemban oleh dosen mesti memperhatian pemakaian kesantunan tindak tutur. Kondisi ideal sebagai bentuk 
pemakaian kesantunan tindak tutur akhir-ahir ini ditemukan pemakaiannya di kalangan mahasiswa calon guru yang diajarkan oleh dosen dan menyebar luas di setiap sekolah menjadi suatu budaya berbahasa santun. Hal inilah yang menjadi perhatian peneliti sehingga penelitian berjudul Kesantunan Tindak Tutur Introgatif Dosen dalam Pembelajaran di Kelas: Studi Kasus di Prodi Pendidikan Bahasa dan Sastra Indonesia FKIP UM Mataram cukup relevan dan penting diangkat di tengah perkembangan zaman.

Penelitian tentang kesantunan sudah banyak dilakukan oleh peneliti sendiri, namun objek kajiannya sangat beragam. Di antara penelitian tersebut yaitu Ajaran Tuan Guru tentang Konsep Kesantunan di Pulau Lombok dan Kesantunan Tindak Tutur Direktif Jamaah Tablig dalam Bedakwah.

Menurut Austin, mengucapkan sesuatu adalah melakukan sesuatu dan di situ ada tindak tutur. Bahasa dapat digunakan untuk "membuat kejadian" (Sumarsono, 2009: 181). Berdasarkan pendapat para ahli di atas, dapat disimpulkan bahwa tindak tutur adalah tindakan yang dinyatakan dengan makna atau fungsi (maksud dan tujuan) yang melekat pada tuturan. Tindak tutur merupakan unit terkecil aktivitas bertutur (percakapan atau wacana) yang terjadi dalam interaksi sosial.

Strategi tindak tutur adalah cara-cara yang digunakan partisipan tutur dalam mengekspresikan tindak atau fungsi tindak tutur menggunakan tuturan tertentu. Dalam kaitan ini, Wijana (1986) mengisyaratkan bahwa strategi penyampaian tindak atau fungsi tindak tutur dapat diwujudkan dengan tuturan bermodus deklaratif, interogatif, dan imperatif (bermakna literal atau nonliteral dan langsung atau tidak langsung). Sejalan dengan hal tersebut, Brown dan Le $\neg$ vinson (dalam Sumarsono, 2010) menyatakan bahwa tuturan yang mengekspresikan tindak tutur pada umumnya menggambarkan strategi penyampaian tindak tutur tersebut.

Para ahli umumnya membedakan strategi penyampaian tindak tutur atas dua jenis, yaitu strategi langsung dan tidak langsung. Blum-Kulka (1989) mengatakan bahwa strategi langsung dan tidak langsung yang digunakan dalam penyampaian tindak tutur berkaitan dengan dua dimensi, yaitu dimensi pilihan pada bentuk dan dimensi pilihan pada isi. Dimensi bentuk berkaitan dengan bagaimana suatu tuturan diformulasikan atau bagaimana ciri formal (berupa pilihan bahasa dan variasi linguistik) suatu tuturan dipakai untuk mewujudkan suatu ilokusi. Dimensi isi berkaitan maksud yang terkandung pada tuturan tersebut. Jika isi tuturan mengandung maksud yang sama dengan makna performasinya, maka tuturan tersebut dituturkan dengan strategi langsung.
Sebaliknya, jika maksud suatu tuturan berbeda dengan makna performasinya maka tuturan tersebut dituturkan dengan strategi tidak langsung (Arifin, 2012).

Dengan mengadaptasi teori-teori tersebut, strategi tindak tutur dapat dibedakan atas strategi langsung dan tidak langsung. (1) Strategi langsung, yaitu strategi penyampaian tindak tutur menggunakan tuturan yang bentuknya mempunyai makna sama (atau mirip) dengan maksud pengutaraannya. (2) Strategi tidak langsung adalah strategi penyampaian tindak tutur menggunakan tuturan yang bentuknya mempunyai makna yang tidak sama dengan maksud penuturannya.

Strategi penyampaian tindak tutur ini penting dipahami untuk mendukung kajian terhadap kesantunan tindak tutur direktif. Strategi penyampaian tindak tutur yang digunakan penutur akan memudahkan kita menganalisis strategi kesantunan yang digunakan, baik kesantunan positif maupun kesantunan negatif sesuai dengan teori kesantunan yang akan diuraikan berikutnya.

\section{B. METODE PENELITIAN}

Penelitian kesantunan ini merupakan salah satu penelitian dalam kajian sosiopragmatik dengan pendekatan deskriptif kualitatif. Asumsi dari desain penelitian kualitatif adalah, penelitian kualitatif lebih menekankan pada proses, bukannya hasil atau produk, peneliti merupakan instrumen kunci atau pokok, peneliti kualitatif melibatkan kerja lapangan, yaitu secara fisik berhubungan dengan orang, latar, lokasi atau institusi untuk mengamati atau mencatat perilaku dalam latar alamiah, dan proses penelitian kualitatif bersifat induktif.

Data penelitian merupakan masalah yang dikaji dalam suatu penelitian (Arikunto, 2009:45). Data penelitian ini ada dua jenis, yaitu (1) data berupa tuturan dosen (Pn) dan (2) data catatan lapangan berupa catatan lapangan deskriptif dan reflektif (termasuk hasil wawancara dengan dosen). Data catatan lapangan deskriptif berisi: (a) rekonstruksi interaksi verbal dalam proses pembelajaran di kelas, (b) gambaran tentang situasi dan karakteristik peserta tutur, topik tutur, dan tujuan tutur. Data catatan lapangan reflektif berisi penafsiran dan pemahaman sementara tentang hal-hal yang berpengaruh terhadap penggunaan kompetensi bentuk, fungsi, dan strategi ajaran dosen disertai hasil wawancara yang relevan. Dalam penelitian ini, tuturan yang digunakan sebagai data adalah tuturan yang bersumber dari dosen sebagai penutur (Pn) dalam proses pembelajaran di kelas. Pengumpulan data dalam penelitian ini berkaitan dengan hal-hal sebagai berikut: (1) persiapan pengumpulan data, (2) teknik observasi, dan (3) teknik wawancara.

Selanjutnya, mengikuti pandangan Miles dan Huberman (dalam Sugiyono, 2006:337), analisis data 
kualitatif dalam penelitian ini terdiri atas tiga alur kegiatan yang terjadi secara simultan, yaitu kegiatan reduksi data, penyajian data, dan verifikasi data atau menarik simpulan. Ketiga kegiatan tersebut saling berinteraksi, berawal dari pengumpulan data dan berakhir pada selesainya penulisan laporan penelitian.

\section{HASIL DAN PEMBAHASAN}

Hasil penelitian yang telah dilakukan dalam proses perkuliahan menunjukkan beberapa bentuk klasifikasi tindak tutur introgatif (pertanyaan). Tindak tutur introgatif yang diungkapkan oleh dosen sangat beragam bergantung sudut pandang penilaian yang digunakan. Berikut ini terdapat klasifikasi jenis-jenis tindak tutur introgatif yang ditemukan dalam proses pengajaran. Klasifikasi tersebut dibagi menjadi dua, yaitu: 1) bentuk tindak tutur introgatif berdasarkan maksud pengajuaannya dapat diklasifikasikan menjadi 4 jenis, yaitu: pertanyaan permintaan, pertanyaan retoris, pertanyaan mengarahkan atau menuntun, dan pertanyaan menggali; dan 2) bentuk tindak tutur introgatif berdasarkan tingkat kesulitan jawaban yang diharapkan dapat diklasifikasikan menjadi 6, yaitu: pertanyaan pengetahuan, pertanyaan pemahaman, pertanyaan aplikatif, pertanyaan analisis, pertanyaan sintesis, dan pertanyaan evaluasi. Klasifikasi bentuk tindak tutur introgatif tersebut akan diuraikan secara terperinci sebagai berikut.

\section{Tindak tutur introgatif berdasarkan maksud pengajuaannya}

Tindak tutur introgatif berdasarkan maksud pengajuaannya dapat diklasifikasikan menjadi 4 jenis, yaitu: pertanyaan permintaan, pertanyaan retoris, pertanyaan mengarahkan atau menuntun, dan pertanyaan menggali. Berikut akan dijelaskan secara terperinci.

a) Tindak tutur introgatif berupa petanyaan permintaan (compliance quention), yaitu tindak tutur berupa pertanyaan yang mengandung suruhan dengan harapan agar peserta tutur dapat mematuhi perintah yang diucapkan. Oleh karena itu, pertanyaan seperti ini tidak mengharapkan umpan balik berupa jawaban lisan dari peserta didik, melainkan berupa tindakan atau reaksi nyata peserta didik. Hal ini terdapat dalam kutipan sebagai berikut.

Dosen: Membaca suatu karya sastra, pembacaan pertama itu jangan terlalu serius karena akan menggunggu proses penikmatan dan hal-hal yang kita dapatkan. Seperti nonton korea, di sini kan sudah jelas konsep apa yang dicari dan kenikmatankenikmatan lain yang akan didapat?

Tuturan tersebut dituturkan oleh dosen untuk menuntut mahasiswa agar patuh terhadap langkahlangkah dalam apresiasi karya sastra. Hal ini sebagaimana dijelaskan bahwa langkah pertama yang harus dilakukan mahasiswa dalam apresiasi karya saastra adalah dengan membaca santai, tidak
Habiburrahman, Kesantunan Tindak Tutur...

dengan terlalu serius. Hal ini dikarenakan konsep yang ditekankan pada dasarnya agar mampu menikmati karya satra tersebut. Jadi pertanyaan tersebut tidak membutuhakan jawaban lisan mahasiswa tentang konsep apa yang akan dicari, melainkan berupa tindakan atau reaksi nyata agar diterapkan sebagai langkah awal dalam kajian apresiasi sastra.

b) Tindak tutur introgatif berupa pertanyaan retoris (rehorical question), yaitu jenis pertanyaan yang tidak menghendaki jawaban dari peserta didik, melainkan untuk dijawab sendiri oleh dosen. Pertanyaan jenis ini merupakan bagian dari retorika berbicara di saat menjelaskan materi di dalam proses pembelajaran. Walaupun bisa digantikan dengan ujaran serupa yang tidak mengandung pertanyaan, pertanyaan retoris diyakini mampu memberi kesan yang lebih bertenaga sekaligus menghidupkan gairah belajar peserta didik. Hal ini terdapat dalam kutipan di bawah ini.

Dosen : Baik, minggu lalu kita sudah mebahas tentang? tentang...? apa..?

Mahasiswa : konsep pembelajaran

Dosen : Ok.. jadi pada minggu lalu kita sudah membahas tentang bagaimana seorang guru untuk menciptakan proses pembelajaran yang baik. Sekarang kita sudah masuk ke ranah strateginya seperti yang saya jelaskan (dosen menjelaskan secara detail tentang strategi pembelajaran)

Tuturan tersebut dituturkan oleh dosen sebagai pengantar awal untuk membuka tuturan sebelum menjelaskan materi secara mendalam tentang materi pembelajaran. Pertanyaan retoris tersebut diyakini mampu memberi kesan yang lebih bertenaga sekaligus menghidupkan gairah belajar peserta didik di awal pertemuan dengan mengingatkan siswa materi pada pertemuan sebelumnya. Dosen tidak semata-mata meginginkan jawaban sebagai bagian dari evaluasi hasil pembelajaran, melainkan untuk dijawab sendiri oleh dosen untuk menajamkan esesnsi pembelajaran tentang stategi pembelajaran inovatif.

c) Tindak tutur introgatif berupa pertanyaan mengarahkan atau menuntun (prompting question), yaitu pertanyaan yang diajukan untuk menuntun proses berpikir peserta didik, dengan harapan mereka dapat memperbaiki atau menemukan jawaban yang lebih tepat dari jawaban sebelumnya. Hal ini terdapat dalam kutipan di bawah ini.

Dosen : Baik sekarang saya akan bertanya tentang pembahasan kemarin. Bagi Sausure tanda itu dibagi dua, yaitu penanda dan petanda. Penanda iu apa? 
Mahasiswa : Penanda itu simbol, misalnya lampu merah

Dosen : Contoh kalimat, "Saya mengumpulkan bunga". Penandanya mana?

Mahasiswa : Bunga.

Dosen : Masa bunga saja, apakah ini bukan penanda?

Mahasiswa : ya kan nanti bunga apa pak?

Dosen :Makanya, ini kan masalah bunga apa itu merupakan pertanyaan selanjutnya. Jadi, Semuanya dapat menjadi penanda karena dapat dirasakan indra (Dosen menjelaskan lebih detail). Jadi, penanda itu apa?

Tuturan tersebut dituturkan oleh dosen untuk menuntun pemahaman mahasiswa tentang petanda dan penanda. Penggunaan pertanyaan di sini diajukan untuk menuntun proses berpikir mahasiswa dengan harapan mereka dapat memperbaiki atau menemukan jawaban yang lebih tepat dari jawaban sebelumnya tentang pemahaman mereka tentang penanda dan petanda.

d) Tindak tutur introgatif berupa pertanyaan menggali (probing question), yaitu petanyaan yang diberikan untuk mendorong peserta didik agar meningkatkan kualitas dan kuantitas jawaban. Jenis pertanyaan ini sangat penting untuk menstimulasi kecerdasan berpikir peserta didik. Hal ini terdapat dalam kutipan di bawah ini.

Dosen :Selanjutnya kita mengenal ada ikon, simbol dan indeks. Hakikat tanda itu kan selalu merujuk kepada sesuatu hal yang lain, kalau kata lukisan? kan lukisan sebagai tanda, terus kalau rujukan yang lain apa? Lukisan dari? Mahasiswa : Lukisan dari si A, si B.

Dosen :Jawabannya itu yang disebut indeks.

Mahasiswa : Indeks ada asap ada api.

Dosen : Jadi bedanya jelas, terakhir simbol?

Mahasiswa : Simbol itu kesepakan, seperti lampu merah itu berhenti.

Tuturan tersebut dituturkan oleh dosen untuk mendorong peserta didik agar meningkatkan kualitas dan kuantitas jawaban. Jenis pertanyaan ini sangat penting untuk menstimulasi kecerdasan berpikir peserta didik. Dosen mengawali tuturan dari pengertian penanda dan petanda sampai pada pertanyaan yang akan mengantarkan mahasiswa dapat membedakan anatar indeks, ikon dan simbol secara mendalam.

\section{Tindak tutur introgatif berdasarkan tingkat kesulitan jawaban yang diharapkan}

Tindak tutur introgatif berdasarkan tingkat kesulitan jawaban yang diharapkan dapat diklasifikasikan menjadi 6, yaitu: pertanyaan pengetahuan, pertanyaan pemahaman, pertanyaan aplikatif, pertanyaan analisis, pertanyaan sintesis, dan pertanyaan evaluasi.

a) Tindak tutur introgatif berupa pertanyaan pengetahuan (knowledge question). Pertanyaan ini merupakan pertanyaan yang memiliki tingkat kesulitan paling rendah. Hal ini dikarenakan untuk menjawabnya, peserta didik hanya mengandalkan kemampuan mengingat fakta, realita atau data. Jawabannya pun sederhana dan tidak memerlukan penjelasan yang terpeinci. Jenis pertanyaan ini juga disebut sebagai recall quetion karena peserta didik dikehendaki untuk mengungkapkan kembali apa yang pernah diperoleh dari pembelajaran sebelumnya, atau berdasarkan wawasan dan pengalaman pribadi peserta didik. Pertanyaan pengetahuan diawali dengan kata: apa, dimana, kapan, siapa, sebutkan dan tuliskan. Hal ini terdapat dalam kutipan di bawah ini.

Dosen: Baiklah diskusi untuk kelompok enam sudah berjalan efeketif sesuai dengan waktu yang ditentukan. Selanjutnya saya akan mengulas kembali beberapa hasil diskusi yang masih diperdebatkan tentang jenis kalimat berdasarkan predikat yang membentuknya. Coba Ainul Imansyah, apa yang Anda pahami tentang kalimat verbal?

Tuturan tersebut dituturkan oleh dosen agar mahasiswa mengungkapkan kembali apa yang pernah diperoleh dari pembelajaran sebelumnya dalam diskusi. Mahasiswa hanya mengandalkan kemampuan mengingat fakta, realita atau data. Jawabannya pun sederhana dan tidak memerlukan penjelasan yang terpeinci, yaitu mahasiswa hanya menjawab pengertian kalimat verbal saja.

b) Tindak tutur introgatif berupa pertanyaan pemahaman (comprehension question). Dilihat dari tingkat kesulitan jawaban yang diharapkan, pertanyaan pemahaman lebih sulit dibandingkan dengan pertanyaan pengetahuan. Hal itu disebabkan pertanyaan ini tidak sekadar mengharapkan peserta didik untuk mengungkapkan kembali apa yang diingatnya, tetapi juga untuk memperjelas gagasan menggunakan kemampuan berpikir. Pertanyaan pemahaman diawali dengan kata: jelaskan, uraikan, dan bandingkan. Hal ini terdapat dalam kutipan di bawah ini. 
Dosen: Baik, tadi sudah bapak jelaskan tentang kalimat verbal dan kalimat nominal beserta contohnya. Sekarang kelompok II, coba jelaskan perbedaan antara kalimat verbal dan kalimat nominal dilihat dari contoh tersebut.

Kutipan yang terdapat dalam tuturan dosen tersebut menunjukkan penggunaan tindak tutur introgatif berupa pertanyaan pemahaman. Tuturan tersebut dituturkan oleh dosen agar mahasiswa memperjelas gagasan menggunakan kemampuan berpikir, yaitu dapat mebedakan secara jelas antara kalimat verbal dan kalimat nominal.

c) Tindak tutur introgatif berupa pertanyaan aplikatif (aplication question). Jenis pertanyaan ini menghendaki peserta didik untuk mengimplementasikan pengetahuan yang dimiliki setelah proses pembelajaran berlangsung. Hal ini terdapat dalam kutipan di bawah ini.

Dosen: Hasil diskusi tentang konsep pembelajaran tadi apa? (siswa disuruh maju menuliskan hasil diskusi tentang metode pembelajaran inovatif) kenapa memilih kata-kata ini?

Tuturan tersebut dituturkan oleh dosen agar mahasiswa mengimplementasikan pengetahuan yang dimiliki setelah proses pembelajaran berlangsung tentang metode pembelajaran inovatif.

d) Tindak tutur introgatif berupa pertanyaan analisis (analysis question). Jenis pertanyaan ini mengharapkan agar peserta didik dapat menguraikan, menarik kesimpulan, mengidentifikasi suatu konsep tertentu. Hal ini terdapat dalam kutipan di bawah ini.

Dosen: Materi kita hari ini adalah mengomentari karya sastra berupa cerpen (dosen menjelaskan tentang materi sebagai pengantar awal langkah-langkah untuk mengomentari suatu cerpen). Baik kita bersama-sama membahas. Ayo kelompok IV uraikan komentar anda tentang isi dari cerpen yang sudah kalian baca tersebut.

Tuturan tersebut dituturkan oleh dosen agar mahasiswa dapat menguraikan, menarik kesimpulan, dan mengidentifikasi karya sastra berupa cerpen dengan memberikan komentar tehadap isi cerpen sebagai bagian dari kegiatan menguraikan isi dan menarik simpulan cerita yang dapat menjelaskan tentang suatu konsep kehidupan. Tidak tindak tutur introgatif berupa pertanyaan analisis ini diawalai dari penjelasan secara terperinci tentang langkah-langkah dalam suatu analisis kemudian dipertanyakan hasil dari kegiatan analisis tersebut.

e) Tindak tutur introgatif berupa pertanyaan sintesis (synthesis quetion). Jenis pertanyaan ini mengharapkan peserta didik memberikan jawaban ringkasan dalam bentuk bagan dari suatu kajian materi pembelajaran. Hal ini terdapat dalam kutipan di bawah ini.

Dosen : Ok.. jadi pada minggu lalu kita sudah membahas tentang bagaimana seorang guru untuk menciptakan proses pembelajaran yang baik. Sekarang kita sudah masuk ke ranah strateginya seperti yang saya jelaskan (dosen menjelaskan secara detail tentang strategi pembelajaran) baik, apa yang kalian pahami tentang strategi pembelajaran inovatif? Silakan pemikiran kalian tuangkan dalam bagan konsep yang disiapkan di depan. (setiap mahasiswa menyiapkan bagan konsep dalam kertas manila tentang materi yang akan dibahas) siap-siap kelompok Bipa sekarang ayo....!

Tuturan tersebut dituturkan oleh dosen agar mahasiswa memberikan jawaban ringkasan dalam bentuk bagan dari suatu kajian materi pembelajaran yang sudah dipahami. Jenis tindak tutur introgatif berupa pertanyaan sintesis ini sering digunakan oleh dosen untuk membahas suatu konsep yang sudah pernah dipahami sebelumnya oleh mahasiswa, baik itu didengar maupun dibaca. Jenis pertanyaan ini tergolong tingkat kesulitannya lebih tinggi dari menganalisis karena mahasiswa memberikan jawaban ringkasan dalam bentuk bagan dari suatu kajian materi pembelajaran berdasarkan pemahaman awal yang dipahami.

f) Tindak tutur introgatif berupa pertanyaan evaluasi (evaluation question). Pertanyaan jenis ini mengharapkan jawaban berupa penilaian atau pendapat tehadap suatu rumor, isu, atau topik suatu pembahasan. Hal ini terdapat dalam kutipan di bawah ini.

Dosen : Abdurrahman bisa membantu Suarni, apa yang harus dilakukan untuk meningkatkan keterampilan menyimak siswa, apasaja yang harus dipersiapkan?

Mahasiswa : Menyiapkan alat bantu seperti audio.

Dosen : Ada lagi, ayo dari kelompok yang presentasi?

Mahasiswa : Mengondisikan siswa bu, dan siswanya tenang. 
Tuturan tersebut dituturkan oleh dosen untuk mengevaluasi pemahaman siswa tentang materi yang didiskusikan dan diberikan penguatan sehingga materi yang masih kurang dipahami dapat dipertegas dengan pertanyaan dosen. Jenis tindak tutur introgatif berupa pertanyaan evaluasi ini dapat meningkatkan pemahaman dan keseriusan mahasiswa untuk memperhatikan kembali materi yang sudah dibahas sehingga dengan mudah dapat menjawab beberapa pertanyaan dosen.

\section{Bentuk Kesantunan Tindak Tutur Introgatif}

Sesuai dengan bentuk tindak tutur introgatif yang diuraikan tersebut, bentuk kesantunan tindak tutur introgatif dapat disepadankan dengan bentuk pengklasifikasian berdasarkan maksud pertanyaan dan tingkat kesulitan jawaban yang dikehendaki. Pada prisipnya, kedua bentuk pengklasifikasian bentuk tindak tutur introgatif tersebut mengancam muka lawan tutur (peserta didik). Hal ini didasari dari kajian strategi kesantunan positif dan negatif berdasarkan kajian Brown dan Levinson. Untuk mengurangi kekecewaan mitra tutur, Brown dan Levinson menawarkan strategi-strategi berikut untuk tindakan yang melanggar wajah positif dan negatif. Bagaimana bentuk strategi itu, tergantung pada jenis kesantunannya, yaitu kesantunan negatif atau kesantunan positif. Berikut didaftarkan strategi untuk kesantunan negatif yang digunakan dalam tindak tutur introgatif.

a) Gunakan pagar (hedge); kesantunan jenis ini digunakan untuk mengurangi ancaman lawan tutur tentang suatu hal yang akan dipertanyakan. Hal ini sebagaimana terdapat dalam kutipan berikut ini.

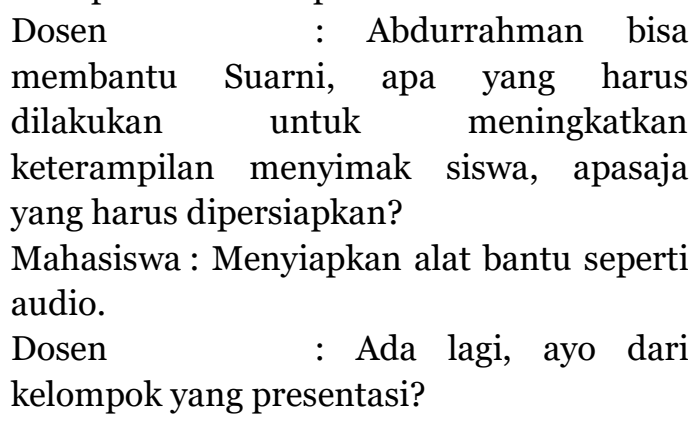

Kutipan yang terdapat dalam tuturan dosen tersebut menunjukkan penggunaan kesantunan tindak tutur introgatif berupa pertanyaan evaluasi hasil diskusi kelompok. Kesantunan dengan cara merberikan pagar berarti pertanyaan tersebut semata-mata dituturkan untuk mengurangi ancaman lawan tutur dengan menjadikan seseorang sebagai alasan agar dia bisa memberikan jawaban. Jadi meskipun salah, ia hanya berpikir membantu jika mampu. Dalam hal ini Suryani dan nama dari kelompok yang disebutkan.

b) Meminimalkan paksaan. Jenis kesantunan ini dapat terukur dari kadar paksaan setiap tuturan yang digunakan. Dengan adanya penggunaan kata coba pada setiap pertanyaan di atas pada dasarnya suatu tuturan dianggap mengurai kadar ancaman terhadap muka lawan tutur. Beberapa tuturan yang mencerminkan penggunaan kesantunan dengan cara meminmalkan paksaan tersebut dapat dilihat dalam kutipan berikut.

Dosen : Baik, tadi sudah bapak jelaskan tentang kalimat verbal dan kalimat nominal beserta contohnya. Sekarang kelompok II, coba jelaskan perbedaan antara kalimat verbal dan kalimat nominal dilihat dari contoh tersebut.

Pada kutipan tuturan tersebut, tindak tutur introgatif ini diawali dengan penggunaan kata coba. Ini menunjukkan bahwa dosen berusaha agar mahasiswa tidak tertekan dengan seperangkat pertanyaan yang dituturkan oleh dosen. Beberapa mahasiswa jika dihadapkan pada suatu kondisi pertanyaan, maka mahasiswa selalu merasa kehabisan cara untuk menghindari pertanyaan, bukan berusaha untuk menjawab. Dengan demikian, jenis kesantunan dengan cara meminimalkan paksaan ini paling banyak digunakan dalam tuturan dosen tersebut.

c) Berikan penghormatan; kesantunan jenis ini digunakan untuk mengurangi ancaman lawan tutur dengan memberikan penghormatan kepada satuan yang lebih besar dalam suatu pembelajaran yaitu kelompok diskusi. Hal ini terdapat dalam kutipan di bawah ini.

Dosen : Ok.. jadi pada minggu lalu kita sudah membahas tentang bagaimana seorang guru untuk menciptakan proses pembelajaran yang baik. Sekarang kita sudah masuk ke ranah strateginya seperti yang saya jelaskan (dosen menjelaskan secara detail tentang strategi pembelajaran) baik, apa yang kalian pahami tentang strategi pembelajaran inovatif? Silakan pemikiran kalian tuangkan dalam bagan konsep yang disiapkan di depan. (setiap mahasiswa menyiapkan bagan konsep dalam kertas manila tentang materi yang akan dibahas) siap-siap kelompok Bipa sekarang ayo....!

Kutipan yang terdapat dalam tuturan dosen tersebut menunjukkan penggunaan kesantunan dengan cara memberikan kesempatan secara adil dan merata kepada setiap kelompok sehingga tidak hanya orang tertentu yang terancam dengan pertanyaan yang diucapkan 
oleh dosen. Penghormatan dalam hal ini diartikan sebagai suatu giliran yang merata sehingga semua memiliki kesempatan yang sama untuk mengungkapkan gagasan mereka masing-masing.

Selanjutnya di daftar strategi-strategi untuk kesantunan positif sebagai berikut.

a) Menhindari ketidak setujuan dengan purapura setuju, persetujuan yang semu (psedo agreement), menipu untuk kebaikan (mhite lies), atau pemagaran opini (hedging opinicon). Hal ini tampak pada kutipan di bawah ini.

Dosen : Ok.. jadi pada minggu lalu kita sudah membahas tentang bagaimana seorang guru untuk menciptakan proses pembelajaran yang baik. Sekarang kita sudah masuk ke ranah strateginya seperti yang saya jelaskan (dosen menjelaskan secara detail tentang strategi pembelajaran) baik, apa yang kalian pahami tentang strategi pembelajaran inovatif? Silakan pemikiran kalian tuangkan dalam bagan konsep yang disiapkan di depan. (setiap mahasiswa menyiapkan bagan konsep dalam kertas manila tentang materi yang akan dibahas) siap-siap kelompok Bipa sekarang ayo....!

Kutipan

tuturan tersebut menunjukkan penggunaan kesantunan dengan menhindari ketidaksetujuan dengan pura-pura setuju, persetujuan yang semu menunjukkan hal-hal yang dianggap mempunyai kesamaan melalui basa-basi. Hal ini dikarenakan pertanyaan dosen tentang masalah yang sama padahal sudah dijwab dalam bagan konsep secara bergantian oleh mahasiswa. Apapun jawaban mahasiswa dalam peta konsep dianggap benar, tinggal diluruskan tentang rumusan jawaban yang sebenarnya.

b) Menunjukkan keoptimisan; kesantunan jenis ini sering digunakan oleh dosen untuk memotivasi siswa agar berusaha maksimal dalam menjawab beberapa pertanyaan yang disampaikan oleh dosen. Hal ini dapat diperhatikan dalam kutipan sebagai berikut.

Dosen: Strategi pembelajaran yang inovatif itu seperti apa menurut anda? kelompok I? (dosen langsung meminta mahasiswa menuliskan jawaban di depan papan tulis secara bergantian sebagai bagian dari pembelajaran inovatif) Ayo yang lain pikirkan, kelompok lain jangan mau ada kalah. Ok.. kelompok yang lain, kelompok bipa apa yang dipahami? (dosen langsung meminta mahasiswa menuliskan jawaban di depan papan tulis secara bergantian) pembelajaran yang inovatif dalam pembelajaran yang berkembang.

Penggunaan kesantunan dengan menunjukkan keoptimisan tersebut tampak dari semangat yang diberikan oleh dosen kepada setiap kelompok agar menyiapkan diri untuk dapat menjawab pertanyaan dosen. Kesantunan jenis ini banyak digunakan oleh dosen untuk meningkatkan kualitas pembeljaran dengan membangkitkan semangat mahasiswa dengan cara menunjukka sikap optimis bahwa mahasiswa dapat menjawab pertanyaan yang dituturkan oleh dosen.

\section{SIMPULAN DAN SARAN}

Berdasarkan pembahasan hasil penelitian yang telah diuraikan tersebut dapat disimpulkan beberapa bentuk klasifikasi tindak tutur introgatif (pertanyaan). Tindak tutur introgatif yang diungkapkan oleh dosen dibagi menjadi dua, yaitu: 1) bentuk tindak tutur introgatif berdasarkan maksud pengajuaannya dapat diklasifikasikan menjadi 4 jenis, yaitu: pertanyaan permintaan, pertanyaan retoris, pertanyaan mengarahkan atau menuntun, dan pertanyaan menggali; dan 2) bentuk tindak tutur introgatif berdasarkan tingkat kesulitan jawaban yang diharapkan dapat diklasifikasikan menjadi 6, yaitu: pertanyaan pengetahuan, pertanyaan pemahaman, pertanyaan aplikatif, pertanyaan analisis, pertanyaan sintesis, dan pertanyaan evaluasi. Sedangkan bentuk kesantunan tindak tutur introgatif dapat dibedakan menjadi strategi kesantunan negatif dan strategi kesantunan positif. Strategi kesantunan negatif ada tiga, yaitu 1) kesantunan dengan menggunakan pagar; 2) kesantunan dengan meminimalkan paksaan; dan 3) kesantunan dengan memberikan penghormatan. Sementara strategi kesantunan positif ada dua, yaitu 1) kesantunan dengan menghindari ketidaksetujuan dengan pura-pura setuju, persetujuan yang semu (psedo agreement), menipu untuk kebaikan (mhite lies), atau pemagaran opini (hedging opinicon); dan 2) kesantunan dengan menunjukkan keoptimisan.

Sesuai hasil penelitian, maka disarankan beberapa hal sebagai berikut: Saran bagi para pengajar, yaitu guru dan dosen dapat menjadikan beberapa bentuk keantunan tindak tutur introgatif sebagai sarana yang efektif dalam pembelajaran untuk meningkatkan keseriusan peserta didik dalam memahami materipembelajaran dan pembentuk karakter pribadi para pengajar sehingga terbentuk manusia yang berkarakater dan beriman untuk menciptakan generasi yang berkaraker santun. 


\section{DAFTAR RUJUKAN}

[1] Arifin. 2012. Bahan Ajar Pragmatik. Universitas Pendidikan Ganesha. Tidak Diterbitkan.

[2] , 2008. Penggunaan Tindak Tutur Siswa dalam Percakapan di Kelas. Disertasi PPs. Universitas Negeri Malang. Tidak Diterbitkan.

[3] Arikunto, Suharmini. 2009. Manajemen Penelitian. Jakarta: Rineka Cipta.

[4] Chaer, Abdul. 2010. Kesantunan Berbahasa. Jakarta: PT. Rineka Cipta.

[5] Chaer, Abdul \& Leonie Agustina. 2010. Sosiolinguistik: Perkenalan Awal. Jakarta: Rineka Cipta.

[6] Holmes, Janet. Tanpa Tahun. An Introduction to Sosiolinguitics (Terjemahan). Tidak Diterbitkan.

[7] Ibrahim, Abd. Syukur. 2005. Kapita Selekta Pragmatik. PPs. Universitas Negeri Malang. Tidak diterbitkan.

[8] Leech, Geoffrey. 1982. Prinsip-prinsip Pragmatik (Terjemahan). Jakarta: Universitas Indonesia.

[9] Lubis, A. Hamid Hasan. 2011. Analisis Wacana Pragmatik. Bandung: Angkasa.

[10] Moleong, J Lexy. 2004. Metodologi Penelitian Kualitatif. Bandung: PT Remaja Rosdakarya.

[11] Nadar, F.X. 2009. Pragmatik dan Penelitian Pragmatik. Yogyakarta:Graha Ilmu.

[12] Pranowo. 2012. Berbahasa Secara Santun. Yogyakarta: Pustaka Pelajar.

[13] Prayitno, Harun Joko. 2010. "Perwujudan Prinsip Kerja Sama, Sopan Santun, dan Ironi Para Pejabat dalam Peristiwa Rapat Dinas di Lingkungan Pemerintahan Kota Berbudaya Jawa” dalam jurnal terakreditasi Kajian Linguistik dan Sastra, Volume 22, No.1, Juni 2010, Jurusan Pendididkan Bahasa Inggris dan Indonesia FKIP UMS.

[14] Prayitno, Harun Joko. 2011. Kesantunan Sosiopragmayik: Studi Pemakaian Tindak tutur direktif di Kalangan Andik SD Berbudaya Jawa. Surakarta: Muhammadiyah University Press Universitas Muhammadiyah Muhammadiyah Surakata.

[15] Shiffrin, Deborah. 2007. Ancangan Kajian Wacana (Terjemahan Unang dkk). Yogyakarta: Pustaka Pelajar.

[16] Suandi, I Nengah. 2008. Pengantar Metodologi Penelitian Bahasa. Singaraja: Universitas Pendidikan Ganesha.

[17] Sugiyono. 2010. Metode Penelitian Pendidikan: Pendekatan Kuantitatif,Kualitatif, dan R\&D. Bandung: Alfabeta.

[18] Sukardi. 2004. Metodologi Penelitian Pendidikan (Kompetensi dan Praktiknya). Jakarta: PT Bumi Aksara.

[19] Sumarsono. 2010. Buku Ajar Pragmatik. Universitas Pendididkan Ganehsa.

[20] Tarigan, Henry Guntur. 2009. Pengajaran Pragmatik. Bandung: Angkasa.

[21] Yule, George. 2006. Pragmatik (Terjemahan Indah Fajar Wahyuni). Yogyakarta. Pustaka Pelajar.

[22] Wijana, I Dewa Putu. 1996. Dasar-dasar Pragmatik. Jakarta: Andi.

[23] Wijana, I Dewa Putu dan Muhammad Rohmadi.2011. Analisis Wacana Pragmatik: Kajian Teori dan Analisis. Surakarta: Yuma Pustaka. 